\title{
Pengaruh Perlakuan Hipotermia Ringan pada Kasus Cedera Otak akibat Trauma Risiko Tinggi Berdasarkan Glasgow Coma Scale dan Kadar Protein TNF- $\alpha$
}

\author{
${ }^{1}$ Josep Hendratno, ${ }^{2}$ Eko Prasetyo, ${ }^{2}$ Maximillian Ch. Oley \\ ${ }^{1}$ Program Studi Ilmu Bedah Fakultas Kedokteran Universitas Sam Ratulangi Manado \\ Indonesia \\ ${ }^{2}$ KSM Ilmu Bedah Divisi Bedah Saraf RSUP Prof. Dr. R. D. Kandou Manado \\ Email: joe_da7508@yahoo.com
}

\begin{abstract}
Mild hypothermia treatment could be a useful method for improving the outcome of neurological treatment in patients with severe traumatic brain injury (TBI). There are several mechanisms underlying this effect inter alia reduction of metabolic rate, attenuation of excitatory amino acid and free radical synthesis, suppression of inflammatory responses, and prevention of blood-brain barrier disruption and brain edema. This study was aimed to obtain the effect of mild hypothermia treatment on Glasgow Coma Scale (GCS) dan TNF- $\alpha$ level among patients with severe TBI. This was an experimental analytical study. Subjects were adults aged 16-45 years, divided randomly into two groups (mild hypothermia and control groups) which were observed within 24 and 72 hours. TNF- $\alpha$ serum level was estimated by using TNF- $\alpha$ in vitro simple step ELISA. The assessments of outcomes were determined by using Glasgow Coma Scale (GCS) during the mild hypothermia therapy. The results showed that there were 20 TBI patients enrolled in this study, divided randomly into two groups. The treatment group, treated with mild therapeutic hypothermia, showed a decrease in TNF- $\alpha$ serum level and improved clinical value of GCS score $(P<0.05)$. Conclusion: Mild hypothermia could significantly improve the GCS score and decrease TNF- $\alpha$ serum level among patients with severe TBI.
\end{abstract}

Keywords: mild hypothermia treatment, TNF- $\alpha$, GCS score,TBI

\begin{abstract}
Abstrak: Terapi hipotermia ringan (HPTr) dapat memperbaiki hasil pengobatan neurologik pada pasien dengan cedera otak traumatik (COT) risiko tinggi. Beberapa mekanisme yang mendasari efek tersebut ialah antara lain pengurangan tingkat metabolisme, atenuasi asam amino rangsang maupun sintesis radikal bebas, penekanan respons inflamasi, dan pencegahan gangguan sawar darah otak serta edema otak. Penelitian ini bertujuan untuk mengetahui pengaruh perlakuan HPTr pada kasus COT risiko tinggi berdasarkan skor Glasgow Coma Scale (GCS) dan kadar TNF- $\alpha$. Jenis penelitian ialah analisis eksperimental. Subjek ialah orang dewasa berusia 16-45 tahun, diacak menjadi dua kelompok yaitu kelompok perlakuan HPTr dan kelompok kontrol. Pengamatan subjek dilakukan pada 24 jam dan 72 jam. Kadar serum TNF- $\alpha$ diperoleh dengan menggunakan metode TNF- $\alpha$ in vitro simple step ELISA. Penilaian klinis dilakukan dengan mengunakan skor GCS pada 24 dan 72 jam perlakuan HPTr. Hasil penelitian mendapatkan 20 penderita COT, dibagi menjadi dua kelompok secara acak. Kelompok perlakuan HPTr menunjukkan kecenderungan penurunan kadar TNF- $\alpha$ serum dan perbaikan nilai klinis dinilai dengan skor GCS $(P<0,05)$. Simpulan: Pada penderita dengan cedera otak traumatik risiko tinggi, terapi hipotermia ringan dapat meningkatkan nilai klinis skor GCS dan menurunkan kadar TNF- $\alpha$ serum secara bermakna.
\end{abstract}

Kata kunci: hipotermia ringan, TNF- $\alpha$, skor GCS, COT 
Cedera otak traumatik (COT) adalah perubahan fungsi otak yang bermanifestasi pada penurunan kesadaran, kejang, koma, atau defisit neurologis. ${ }^{1} \mathrm{Di}$ Amerika, sekitar 1,4 juta orang mengalami COT setiap tahunnya, dengan tingkat mortalitas sekitar 55.000 yang mengalami kematian. ${ }^{1}$ Di Indonesia, menurut Riskesdas 2007 proporsi bagian tubuh yang cedera dengan melibatkan kepala sekitar 19,6\%; sebagian besar penyebabnya ialah perdarahan intrakranial yang dapat menyebabkan kematian. ${ }^{2}$ Pengunaan HPTr dapat menurunkan akumulasi leukosit polimorfonuklear yaitu mengurangi aktivasi neutrofil terhadap mikroglia. Hal tersebut akan menekan respon inflamasi akut dan subakut yang secara potensial dapat mengurangi aktivasi TNF- $\alpha$; biasanya diikuti oleh berkurangnya risiko terjadi cedera otak sekunder. ${ }^{3}$

Tumor necrosis factor (TNF) adalah molekul peptida yang melakukan aktivitas biologik melalui interaksi dengan reseptor berafinitas tinggi. TNF- $\alpha$ manusia disintesis sebagai prekursor polipeptida terikat membran $(26 \mathrm{kDa})$ yang akan mengalami pembelahan proteolitik untuk menghasilkan bentuk terlarut (17 kDa) yang membentuk polipeptida trimer aktif. ${ }^{4}$ Sitokin proinflamasi ini diproduksi pada stimulasi oleh monosit, makrofag, limfosit $\mathrm{T}$ dan $\mathrm{B}$, neutrofil, dan sel mast. Selain itu, cedera otak iskemik atau traumatik meng-nduksi sintesis peptida prekursor TNF- $\alpha$. Selanjutnya, proTNF- $\alpha$ akan mengaktifkan enzim proteolitik yang menghidrolisis membran proTNF- $\alpha$ yang terikat membran, dan melepaskan $\mathrm{TNF}-\alpha$ yang larut ke dalam ruang ekstrasel. ${ }^{4}$ Menurut Prasetyo et al. ${ }^{5}$ penggunaan hipotermia ringan (HPTr) secara bermakna meningkatkan luaran klinis skor FOUR pada penderita COT, serta mencegah meningkatnya inflammatory transcript factor NFkB yang merupakan regulator promotor kadar MMP-9. Penelitian ini bertujuan untuk mengetahui pengaruh HPTr pada kasus COT risiko tinggi terhadap skor Glasgow coma scale (GCS) dan kadar TNF- $\alpha$ serum agar dapat membantu para klinisi dalam menentukan prognosis dan peningkatan mutu pena- nganan kasus COT risiko tinggi di rumah sakit.

\section{METODE PENELITIAN}

Penelitian ini dilakukan di RSUP Prof. Dr. R. D. Kandou Manado sejak September hingga Desember 2017. Jenis penelitian ialah eksperimental analitik. Subyek penelitian ialah 20 penderita COT risiko tinggi yang dibagi menjadi dua kelompok secara acak, yaitu kelompok kontrol dan kelompok perlakuan HPTr yang diteliti dalam waktu 24 dan 72 jam perawatan.

Kadar TNF- $\alpha$ serum diestimasi dengan menggunakan TNF- $\alpha$ in vitro enzymelinked immun sorbent assay (ELISA) sedangkan penilaian klinis dengan mengunakan skor GCS pada 24 dan 72 jam selama dilakukan HPTr. Tindakan HPTr terhadap penderita COT risiko tinggi dengan melakukan penurunan suhu tubuh normal menjadi $34-36^{\circ} \mathrm{C}$ mengunakan kompres es pada seluruh tubuh penderita (surface cooling). Tindakan HPTr terdiri atas tiga fase yakni fase induksi, dilakukan dua jam pasca COT; fase pemeliharaan/maintenance; dan fase penghangatan/rewarming $\left(0,51^{\circ} \mathrm{C} / \mathrm{jam}\right)$ dengan total waktu keseluruhan 72 jam.

Data yang diperoleh dikumpulkan dan dianalisis menggunakan program SPSS secara univariat dan bivariat pada batas kemaknaan $\alpha=5 \%$, dan untuk perbedaan perubahan kadar protein TNF- $\alpha$ serum digunakan Levene's Test.

\section{HASIL PENELITIAN}

Penelitian ini dilakukan di RSUP Prof. Dr. R. D. Kandou Manado sejak bulan September hingga Desember 2017. Subyek penelitian ialah 20 orang penderita COT risiko tinggi yang dirawat di RSUP Prof. Dr. R. D. Kandou Manado dan memenuhi kriteria inklusi.

Pengaruh tindakan HPTr terhadap kadar protein TNF- $\alpha$ serum pada saat tiba, serta setelah 24 jam dan 72 jam perlakuan dapat dilihat pada Tabel 1 dan Gambar 1. Kadar TNF- $\alpha$ serum setelah 24 jam dari kelompok kontrol dan kelompok perlakuan berbeda bermakna $(P<0,05)$. Demikian 
pula kadar TNF- $\alpha$ setelah 72 jam dari kelompok kontrol dan kelompok perlakuan berbeda bermakna $(P<0,05)$.

Pengaruh terapi HPTr terhadap skor GCS dapat dilihat dalam resume analisis pada Tabel 2 dan Gambar 2. Terdapat perbedaan skor GCS antara kelompok perlakuan HPTr dan kelompok kontrol pada pengamatan setelah 24 jam dan 72 jam. Hasil analisis menunjukkan bahwa setelah 24 jam, kelompok terapi HPTr dan kelompok kontrol tidak memiliki pengaruh yang berbeda bermakna terhadap perubahan skor GCS $(P$ $>0,05)$. Pengaruh berbeda pada kelompok terapi HPTr dan kelompok kontrol terhadap perubahan skor GCS meningkat secara bermakna $(P<0,05)$ setelah 72 jam HPTr. Pengaruh HPTr pada kelompok perlakuan terhadap skor GCS secara bermakna meningkat hampir 3 kali lipat $(P<0,05)$ dengan rerata 6,2 dibandingkan kelompok kontrol dengan rerata 3,0.

Tabel 1. Perubahan $(\Delta)$ nilai TNF- $\alpha$ pada kedua kelompok (Independent samples test)

\begin{tabular}{lccccccc}
\hline & & & \multicolumn{3}{c}{$\begin{array}{c}\text { Levene's test for } \\
\text { equality of } \\
\text { variances }\end{array}$} & \multicolumn{2}{c}{ T-test for equality of means } \\
& & & & & & Sig. \\
& & F & Sig. & T & df & (1-tailed) \\
\hline TNF- $\alpha 24$ jam & Equal variances assumed & 10,965 & 0,004 & 2,803 & 18 & 0,006 \\
TNF- $\alpha$ 72 jam & Equal variances assumed & 0,564 & 0,463 & 14,811 & 18 & 0,0001 \\
\hline
\end{tabular}

Tabel 2. Perubahan $(\Delta)$ Nilai skor GCS pada kedua kelompok

\begin{tabular}{lcccc}
\hline & \multicolumn{4}{c}{ Rerata nilai standar deviasi } \\
\hline Kelompok & 24 jam & 72 jam & Rerata & $\mathrm{P}$ \\
Kontrol & $5,7 \pm 0,48$ & $8,7 \pm 1,77$ & 3,0 & $0,005^{* * *}$ \\
HPTr & $5,7 \pm 0,48$ & $11,9 \pm 2,77$ & 6,2 & $0,005^{* *}$ \\
\hline
\end{tabular}

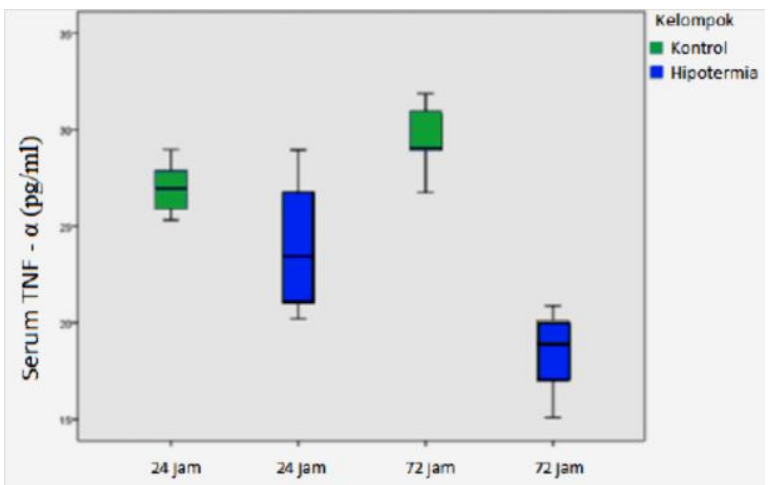

Gambar 1. Box and Whisker perubahan kadar TNF- $\alpha$ serum pada 24 jam dan 72 jam perlakuan HPTr

\section{BAHASAN}

Pada penelitian ini dianalisis 20 penderita COT risiko tinggi untuk mengetahui pengaruh terapi HPTr terhadap perubahan kadar serum TNF- $\alpha$ dan skor GCS pada penderita COT risiko tinggi. Hasil peneli-

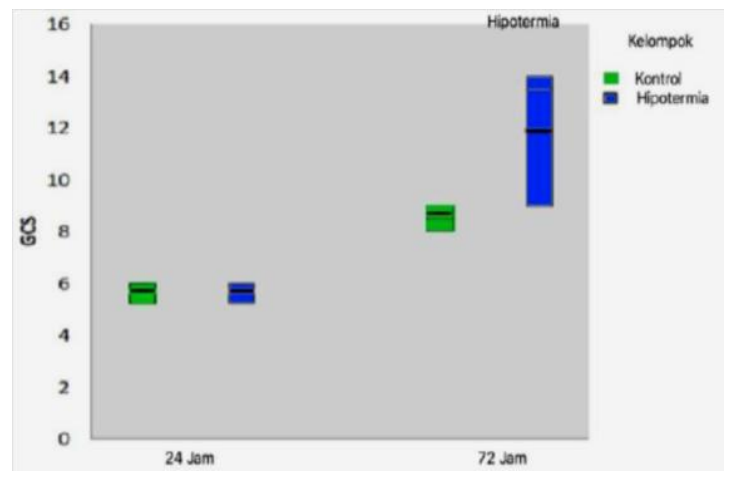

Gambar 2. Box and Whisker perubahan skor GCS pada 24 jam dan 72 jam perlakuan HPTr

tian mendapatkan bahwa terapi HPTr secara bermakna menurunkan kadar TNF- $\alpha$ serum. Dalam penelitian ini dilakukan pemeriksaan kadar TNF- $\alpha$ serum terhadap dua kelompok dimana didapatkan perbedaan bermakna setelah 24 jam antara kadar 
kadar TNF- $\alpha$ serum kelompok perlakuan (23.940 pg/mL) dibandingkan kelompok kontrol $(26.960 \mathrm{pg} / \mathrm{mL})$ dengan $P<0,006$ $(P<0,05)$. Demikian pula kadar TNF- $\alpha$ serum setelah 72 jam pada kelompok perlakuan $(18.564 \mathrm{pg} / \mathrm{mL})$ berbeda bermakna dibandingkan kelompok kontrol 72 jam $(29.460 \mathrm{pg} / \mathrm{mL})$ dengan $P<0,001 \quad(P$ $<0,05)$. Berdasarkan perubahan skor GCS juga didapatkan perbedaan bermakna antara kelompok perlakuan HPTr dan kelompok kontrol $(P<0,05)$.

Penurunan respon inflamasi terhadap terapi HPTr pada penderita COT menginduksi penurunan bermakna dari kadar TNF- $\alpha$ di jaringan otak dalam waktu 24-72 jam akibat kerusakan otak sekunder. ${ }^{6}$ Hayashi et al. ${ }^{7}$ menyatakan bahwa hipotermia sebagai neuroproteksi merupakan salah satu penanganan terhadap cedera otak akibat trauma risiko tinggi. Hipotermia merupakan salah satu mediator penghambat jalur terjadinya cedera otak sekunder. Menurut Mtaweh et al, ${ }^{8}$ beberapa jalur biokimia dapat menyebabkan terbebasnya produksi inflamasi radikal yang keluar saat terjadi cedera otak akibat trauma pada sistem saraf pusat yang sangat berpengaruh pada kerusakan neuronal dan glial pada tahap kelangsungan hidup sel, baik di tingkat fungsi vaskular maupun proses neuroinflamasi di otak.

Meskipun pada tingkat mRNA TNF- $\alpha$ di hipokampus telah berkurang secara bermakna pada penderita COT setelah diberikan hipotermia, kadar protein TNF- $\alpha$ nanti berubah setelah 3 jam pada suhu $33^{\circ} \mathrm{C}$. Hal tersebut menunjukkan bahwa hipotermia dapat menurunkan ekspresi reseptor TNF- $\alpha$ serta pergeseran sinyal proses apoptosis untuk kelangsungan kehidupan sel otak. ${ }^{8}$ Menurut Prasetyo et al. ${ }^{5}$ terapi HPTr dapat mengurangi aktivasi dari NFKB setelah iskemia serebral. NFkB diketahui sebagai pengatur promotor MMP-9. NFкB juga dapat meningkatkan kematian sel neuron in vitro dan banyak gen target $\mathrm{NF} \kappa \mathrm{B}$ diregulasi di fase akut yang terlibat dalam respon inflamasi potensi cedera iskemik pada iskemia serebral. Interaksi dinamik antara faktor transkripsi dan jalur transduksi sinyal merupakan peran mendasar dari terapi HPTr.

Adelson et al. ${ }^{9}$ meneliti respon neuroinflamasi seluler terhadap hipotermia pasca trauma dengan menggunakan tehnik hipotermia pada suhu target $32^{\circ} \mathrm{C}$ selama 4 jam dan mendapatkan bahwa pada hipotermia terjadi penurunan neutrofil akut hingga empat kali lipat akumulasi meskipun tidak berefek pada jumlah neutrofil perifer. Hipotermia pasca trauma secara bermakna menurunkan permeabilitas sawar darah otak pada 3 dan 7 hari setelah cedera. TNF$\alpha$ ialah sejenis protein yang menurunkan kerusakan lamina basal yang menyebabkan terganggunya sawar darah otak. ${ }^{9}$

Prasetyo et al. ${ }^{10}$ menyatakan bahwa pengunaan hipotermia ringan secara bermakna meningkatkan luaran klinis dari skor GCS pada penderita COT, serta mencegah meningkatnya inflammatory transcript factor NFkB yang merupakan regulator promotor kadar MMP-9.

\section{SIMPULAN}

Dari hasil penelitian ini dapat disimpulkan bahwa perlakuan HPTr dapat meningkatkan nilai klinis skor GCS dan menghambat kenaikan kadar protein TNF- $\alpha$ serum secara bermakna pada penderita COT risiko tinggi dalam 24 dan 72 jam perlakuan. Diharapkan agar HPTr dapat dimanfaatkan dalam meningkatkan tingkat kesadaran klinis pasien.

\section{SARAN}

Disarankan untuk penelitian lanjut dalam waktu lebih panjang dengan jumlah sampel yang lebih besar disertai uji pasca penelitian di beberapa rumah sakit untuk memperoleh validitas eksternal yang baik dan dapat menjadi bagian dari pedoman pada pelayanan penderita COT risiko tinggi. Selain itu, penelitian tersebut dilengkapi dengan penanda biologik yang berperan pada target yaitu berkaitan dengan sawar darah otak.

Sebaiknya dilakukan penelitian yang dilengkapi dengan tambahan skala keluaran lainnya baik secara klinis maupun anatomis dan diharapkan dapat dijadikan standar 
operasional prosedur pada penderita COT di masa depan.

\section{DAFTAR PUSTAKA}

1. Bruns J, Hauser WA.The epidemiology of traumatic brain injury. A review. Epilepsia. 2003;44(10 Supl):2-10.

2. Riyadina W, Suhardi PM. The pattern and sociodemography determinant of traffic injury in Indonesia. MKI. 2009;59(10): 464-72.

3. Lucas CL, Lenardo MJ. Molecular basis of cell death programs in mature $\mathrm{T}$ cell homeostasisanuary 2014; p. 41-59. Doi 10.1007/978-1-4614-9302-0 41-51

4. Kushi H. The clinical issue and effectiveness of brain hypotermia treatment for severly brain injured patient. In: Hayashi N, editor. Brain Hypotermia. Tokyo: Springer-Verlag, 2000; p. 121-51.

5. Prasetyo E, Islam AA, Hatta M, Widodo D, Pattelongi I. Downregulation of MMP9 level and GCS score improvement in severe traumatic brain injury due to the mild hypothermia therapy. American Journal of Medical and Biological Research. 2017;5(2):18-22.

6. Zhang Z. Mild hypothermia therapy reduces blood glucose and lactate and improves neurologic outcomes in patients with severe traumatic brain injury. J Crit Care. 2011;26:311-5.
7. Hayashi N, Kushi H, Utagawa A, Kinoshita K, Izumi T, Tanjoh $K$, et al. The clinical issue and effectiveness of brain hypothermia treatment for severly brain-injured patients. In: Hayashi N, editor. Brain Hypothermia. Tokyo: Springer-Verlag, 2000; p. 121-51.

8. Mtaweh D, Simon D, Bell MJ. Hypothermia for traumatic brain injury: Current evidance and future directions. In: Heidenreich KA, editor. New Therapeutics for Traumatic Brain Injury. Prevention of Secondary Brain Damage and Enhancement of Repair and Regeneration. Elsevier, 2017; p. 19-30. Available from: https://www.science direct.com/science/book/97801280268 61.

9. Adelson P, Ragheb J, Kanev P, Brockmeyer D, Beers SR, Brown SD, et al. Phase II clinical trial of moderate hypothermia after severe traumatic brain injury in children. Neurosurg. 2015;56(4):740-54.

10. Prasetyo E, Islam AA, Hatta M, Wiododo D, Pattelongi I. The profile of MMP-9, MMP-9 mRNA expression, $1562 \mathrm{C} / \mathrm{T}$ polymorphism and outcome in highrisk traumatic brain injury: The effect of therapeutic mild hypothermia. Neurol Med Chir (Tokyo). 2017; 57(11):612-9. 